\title{
Finnish Teachers Exploring Gender Bias in School Textbooks
}

\section{Tainio, Liisa}

Routledge

2015

Tainio , L \& Karvonen , U 2015 , Finnish Teachers Exploring Gender Bias in School

Textbooks . in S Mills \& A S Mustapha (eds), Gender Representations in Learning Materials

: International Perspectives . Routledge Studies in Sociolinguistics, no. 9 , Routledge , New

York , pp. 124-149.

http://hdl.handle.net/10138/230991

acceptedVersion

Downloaded from Helda, University of Helsinki institutional repository.

This is an electronic reprint of the original article.

This reprint may differ from the original in pagination and typographic detail.

Please cite the original version. 


\title{
8 Finnish Teachers Exploring Gender Bias in School Textbooks
}

\author{
Liisa Tainio and Ulla Karvonen
}

Finland has a reputation as a country where equality between the sexes has been established with good success. In this chapter we investigate school textbooks for basic education in Finland. First, we explore gender bias and its manifestations in 59 textbooks. Second, we analyse teachers' observations on and attitudes towards gender ideologies presented in school textbooks, when they make comments about gender in these books. We found that there still is gender bias in school textbooks, although there are traces of change. Teachers are able to notice gender bias if they are guided to pay attention to it. However, we found that it was extremely rare for them to talk about boys and girls in terms other than binary opposition.

\section{INTRODUCTION}

The Nordic countries, including Finland, have widely been seen as examples of how gender equality can be implemented in basic education. All children have the same right to attend school and can expect that their personal characteristics, orientations and opinions to be valued within the framework of the Nordic national curricula that promote human rights and democracy, as well as gender equality. For example, the Finnish national curriculum mentions that girls and boys should be given 'the ability to act on the basis of equal rights and responsibilities in society, working life, and family life' (National Curriculum 2004:12). All in all, Finland is known for being a country where equality between the sexes has been established very successfully. There are practically no differences in students' learning results between schools in different parts of Finland (Kupari et al 2013). However, what is remarkable is that the gap between boys' and girls' results in Finland is the widest among OECD countries (Kupari et al 2013). Many researchers have indeed pointed out that everyday practices in schools might still support stereotypical gender roles for young people and thus also support the dichotomy between the sexes (e.g. Gordon, Holland and Lahelma 2000; Tainio 2011). 
Often mentioned in international discussions is that in Finland and in the other Nordic countries, gender bias in school textbooks is not particularly extensive and has further diminished within recent decades (Blumberg 2007). However, in most countries around the world, researchers have shown that gender bias in school textbooks is still strong: females are underrepresented, and both sexes are depicted in gender-stereotyped ways (Blumberg 2007). Further, in spite of the positive development concerning other aspects of education, to some extent this also seems to apply to school textbooks in Finland and other Nordic countries (e.g. Ohlander 2010a, 2010b). Both earlier and more recent studies on gender bias in Finnish textbooks have shown that much still remains to be done (Lahelma 1992; Aapola, Gordon and Lahelma 2003; Tainio and Teräs 2010).

In this chapter we investigate textbooks for basic education used in schools for Finnish speakers. First, we wish to determine if any gender bias remains in the newest textbooks and how this possible bias is manifested. Second, we are interested in Finnish teachers' observations on and attitudes towards gender ideologies presented in school textbooks. To investigate gender bias we analyse both the texts and the visuals of the textbooks, giving examples of different treatments of gender. We analyse a large body of textbooks (altogether 59 books, including exercise books), and focus on three subjects, namely Finnish language and literature, ${ }^{1}$ mathematics and educational and vocational guidance. According to the textbook publishers' websites, the books to be analysed comprise all textbooks currently (2014) in use in Finnish comprehensive schools in these subjects at certain grades.

First, we give an overall description of our data and methods here (see more details about them and the specific objects of the analysis in Section 3). The data consist of textbooks for mathematics and mother tongue and literature in grade 3 (students about 9 years of age), grade 6 (students about 12 years of age) and grade 9 (students about 15 years of age), as well as for educational and vocational guidance, a subject learned in the higher grades of comprehensive school (grades 7-9; students ages 13-16 years). In the analysis, we describe the data by applying the method of critical discourse analysis (e.g. Fairclough 1989; Lazar 2005). Critical discourse analysis (CDA) sees language use as a social practice; CDA is used as an umbrella term for linguistic analyses that investigate the ways power and inequality is enacted in language use. For exploring the written texts, we use the descriptive textual analysis that enables us to see how the sexes are represented in the school textbooks.

In order to trace teachers' attitudes, we analyse discussions between teachers while they study a set of textbooks for mother-tongue education and comment on any evident gender organisation or gender bias in these books. The books the teachers examine are a selection of those that are included in our data. The teachers were instructed to apply the thinking-aloud 


\section{Liisa Tainio and Ulla Karvonen}

protocol to make their attitudes observable to the other participant/s (e.g. Sasaki 2008). Our conversational data consist of a discussion between two primary-level teachers at a comprehensive school (grades 1-6; analysing textbooks for the sixth grade) and another between comprehensive-school upper-grades subject teachers (grades 7-9; analysing textbooks for the ninth grade). The teachers in the dyadic situations were asked to pay attention to the gendered aspects of the textbooks. To analyse this video-recorded data, we applied conversation analysis (e.g. Sidnell and Stivers 2013; Wooffitt 2005). Conversation analysis (CA) aims to study spoken interaction, and it focuses on exploring everyday routines and practices for understanding the interaction from the point of view of participants. This method is often included as one of the methodological tools used in discourse analytic studies (e.g. Fairclough 1989).

\section{TEXTBOOKS AND THE FINNISH DISCOURSE ON GENDER AND EDUCATION}

In many studies, teachers are reported to rely heavily on textbooks in their teaching (Blumberg 2007; Luukka et al 2008; Nygård Larsson 2011; Hickman and Portfilio 2012). For instance, in Finland several studies have shown that the content of textbooks influences teaching practices (Norris et al 1996; Mikkilä-Erdman et al 1999). More recent studies have suggested that Finnish teachers consider textbooks to be a powerful source for their teaching. For example, 76 per cent of mother-tongue teachers and 98 per cent of second- or foreign-language teachers report using textbooks often or very often (Luukka et al 2008:90-98). Of course, teachers can use textbooks in different ways, including critically (Sunderland 2000), but they still use them in designing and planning their own teaching, and students are expected to read them. Texts always involve and communicate values and ideologies, and school textbooks are no exception (Oteiza 2003). Also, textbook authors and illustrators insert attitudinal content in the texts and visuals, even if they aim to be neutral and objective (Oteiza and Pinto 2008).

In Finland, school textbooks are designed in the spirit of the national curriculum, but there is no official examination of the material by the state. The suitability of the textbooks for teaching is assessed by the teachers themselves. In educational contexts, textbooks are used by teachers and students as institutionalised texts that are produced for the purpose of education (Aapola, Gordon and Lahelma 2003; Tainio and Winkler 2014). Textbook authors are usually experienced teachers or researchers, and they work as a team. In their writing of the text, the authors aim to create objective expressions, eliminating, for example, attitudinal meta-discourse, such as modal verbs and commentary adjuncts that could be read as indicators of uncertainty (Martin and Rose 2007). The style of textbooks can 
thus be described as authoritative, factual, objective and general (Palmu 2003; Oteiza and Pinto 2008). Textbooks consist of different types of texts (e.g. factual texts, instructions, lists, exercises, examples) as well as visuals (e.g. illustrations, photographs, cartoons). Martin and Rose (2012) identify textbooks as representatives of a macro genre and refer to them as collections of different kinds of shorter genres. The final textbook product is a realisation of a mixture of various and even contradictory goals by different actors involved in the textbook's making: being pedagogically accurate but still entertaining, considering the demands of science as well as students' interests and earlier knowledge and taking into account the ideas of the authors and the illustrators as well as the editor's and the publisher's instructions (Oteiza 2003).

In Finland, gender bias and the representation of gender have been examined in the textbooks of several subjects. A pioneering analysis was Lahelma's (1992) study of school textbooks. She found that women were presented as being caring in the family and in society and men as more capable of holding powerful positions. Women have often been found to be underrepresented and even invisible, particularly in history textbooks (Lahelma 1992; also Väisänen 2005). Studies on Finnish school textbooks for subjects such as biology (e.g. Aapola, Gordon and Lahelma 2003), religious education (e.g. Korhonen 2010; Kastarinen 2012), ethics (e.g. Lehtinen 2011), health education (e.g. Kosonen et al 2009; Karvonen 2011) and second- and foreign-language education (e.g. Piironen 2004; Laakkonen 2007), have reported gender bias and stereotyped images of gender but have also noted some progress in gender images with a slightly larger amount of nonstereotypical representation of females and males. However, what seems to be constant is a lack of information on the diversity of sexualities and particularly on the diversity of sexes (see also Moon 2012). For example, nonheterosexual relationships and identities have received only minimal attention (e.g. Mietola 2001; Karvonen 2011), and the diversity of sexes remains invisible. Both of these tendencies can be seen as a consequence of describing males and females within a gender-stereotypical framework.

As we will be focusing on textbooks for three subjects, we will first take a brief look at the gender research on textbooks for these subjects in the Finnish context. Studies on textbooks for vocational and educational guidance are few. Lahelma (1992) found that the concept of labour seemed to refer more to men's work than women's and that the traditional segregation of gender in the domain of work was depicted in texts and visuals. She argued that textbooks did not encourage women and men to choose a nongender-stereotypical profession (Lahelma 1992; see also Aapola, Gordon and Lahelma 2003). In studies on mathematics textbooks, both the texts and visuals have been seen to support gender stereotypes, for example in depicting men and women in professions that have traditionally been seen as suitable for their gender (Hannula 1998; Vaahtokari and 


\section{Liisa Tainio and Ulla Karvonen}

Vähäpassi 1998). Women and girls are underrepresented both in texts and in illustrations, and in books men and boys are depicted in a greater variety of activities and professions than women and girls (Kallio and Rehn 2003; Rantanen 2009). Analyses of mother-tongue and literature textbooks show that in these books as well, women tend to receive less attention than men, and gender images follow traditional schemas, in both factual texts and fiction (Palmu 2003; Grünthal 2002). The ABC books contain a majority of male fictional characters (Palmu 1992). References to various authors are overwhelmingly references to men (Palmu 2003). However, all of these studies report analysing only a few books and also not the most recent. In this light, the aim of the project is to take a fresh look at a larger amount of data, including the content of some of the current textbooks.

Studies on Finnish teachers' attitudes towards gender consist mostly of ethnographical or discourse analytic studies on the practices of classroom interaction and thus can provide only indirect information on these attitudes (e.g. Tolonen 2001; Tainio 2010; Tainio 2011; Paju 2011; Skinnari 2012; Riitaoja 2013; Hoikkala and Paju 2013). Although a large body of educational research has used teacher interviews or questionnaires as sources of data for investigating Finnish teachers' thinking, only a few studies have been directly interested in the teachers' attitudes towards gender (however, see Tarmo 1991; Lampela 1995; Palmu 2003; Mäkinen 2009). In these studies, the main result is that, if asked, the teachers see the school and their own teaching as following the principle of gender equality. They see themselves as treating boys and girls equally, and they claim to find differences only between individuals, not between the sexes. This is understandable, since the national curricula promote gender equality and teachers are expected to follow this principle in their work. However, when asked about their deeper views in this area, teachers seem to see boys and girls as differing in their motives and behaviour at school (Tarmo1991; Lampela 1995; Palmu 2003; Mäkinen 2009). This attitude accords well both with ethnographical observations and with the general discussion in the Finnish media, where the prevailing worry about boys' underachievement in comprehensive school and secondary school takes up considerable space (Jungar 2013; Lahelma 2000). In this discussion, the fact that the majority of teachers are women is presented as the main reason for boys' problems in education, since female teachers are not seen as understanding the special needs of boys (Jungar 2013).

In an earlier study on two teachers discussing textbooks from the point of view of gender equality (Tainio 2012), the teachers were found to pay little attention to gender issues, even though they were instructed to do so. However, the teachers were able to recognise traces of gender bias in certain visuals and in the orientations to the history of literature. All in all, it became clear that even if these two teachers had been trained as subject teachers and thus had expertise in text analysis, they were able to spot only the most 
obvious gender issues. However, the discussion revealed more about what teachers have in mind when selecting a textbook, and gender issues seemed not to be among them. In this essay, the discourses on gender in teachers' discussions about textbooks are investigated in more detail.

\section{DATA AND METHODS}

In this chapter, learning materials for three subjects and three grades in Finnish basic education are analysed from the point of view of gender. The analysed material consists of all textbooks used in Finland in 2014, according to the websites of the biggest publishers of school textbooks. ${ }^{2}$ This includes 33 books for mother tongue and literature, 23 for mathematics, and 3 for vocational and educational guidance.

These three subjects were selected for several reasons. First, in basic education more lessons are given in mathematics and mother tongue and literature than in any other subject. Their aim is to help students achieve the most important skills for coping in society, namely learning skills, writing skills and a basic knowledge of mathematics (see Tainio and Grünthal 2012; Hannula, Juuti and Ahtee 2007). Second, these subjects in particular seem to be seen as gendered, at least in the Finnish context, with mother tongue and literature being a 'girls' subject' and mathematics a 'boys" (Suortamo et al 2010). These stereotypes may perhaps be partly responsible for the gap between learning outcomes in these subjects. Girls achieve better results in mother tongue and literature throughout basic education (e.g. PISA 2012). In mathematics, boys achieve better results in some subfields, though in the latest PISA evaluation girls performed on average slightly better than boys (Kupari et al 2013). However, boys are more motivated as learners of mathematics than girls (Mattila 2005; Huisman 2006; Niemi 2008). ${ }^{3}$ Third, we wanted to include educational and vocational guidance in the selection of subjects, since it is an important subject in helping students to find their place in society. Analyses of teaching practices and individual guidance in this subject suggest that they are not free from gender stereotyping (Juutilainen 2003). All in all, these three subjects together form an important basis upon which students can reflect on their own gender identity in the school context and in their future lives, and they also form an adequate basis for an analysis of textbook in basic education.

The analysis was conducted using discourse analysis as a reference point (see e.g. Kress 1985; Fairclough 1989; Pietikäinen 2003; Oteiza 2003; Lazar 2005). Within a discourse analysis it is possible to use several practical methods to explore the data. To quantitatively analyse the texts and visuals we used content analysis (see e.g. Krippendorff 2003). Following critical discourse analysis, we take it for granted that the values and ideologies that texts involve are communicated to the reader in the reading process (e.g. 


\section{Liisa Tainio and Ulla Karvonen}

Oteiza 2003). These ideologies are both overt and covert, and readers use different strategies to cope with them: they can intentionally accept them, they can resist them, or they can relate to them without being intentionally aware of this process. Critical discourse analysts refer to the concept of naturalisation when they describe the power of linguistic and semiotic features that communicate ideologies to the extent that the ideology is considered as the natural state of affairs by the recipients (Fairclough 1989:91-93; Apple and Christian-Smith 1991). The more systematic and dominant these ideological features are, the more invisible and influential they become for the reader. According to Fairclough (1989:92), if a particular ideology is dominant enough, it not only becomes invisible but is also dealt with as the core of the institution it represents. This means that it is important to explore textbooks used in schools, because, since they are used in this context, they are treated as representing the ideology of the institution. In her analysis of history textbooks in Chile, Oteiza claims that school textbooks have 'the power to impose cultural meanings and to structure student's perceptions of reality' (Oteiza 2003:640). She also claims that history textbooks 'tend to reflect an official and naturalized view of history' (Oteiza and Pinto 2008:333). This chapter takes as its starting point the view that the cultural meanings and ideologies of gender are also prominently displayed in school textbooks, although often in hidden ways (Kress 1985; Ohlander 2010a, 2010b; Lazar 2005).

The teachers' conversations and interviews were analysed by using conversation analysis (e.g. Schegloff 2006). Conversation analysis offers us tools for analysing the actual formation of stance-taking that influences the overt and covert attitudes which emerge in the course of the conversation (Heritage and Stivers 2013). This allows us to see how the discussion of gender evolved.

\section{VISUALS, GENDER-SPECIFIC WORDS AND PASSAGES ABOUT GENDER IN TEXTBOOKS}

We are interested in three areas in which gender bias can be seen to emerge in textbooks: visuals, references to males and females in texts and passages that involve information or a discussion on sex or gender (e.g. Palmu 2003; Tainio and Teräs 2010; Tainio 2012). First, gender bias in visuals is explored by counting the number of persons or gendered fantasy characters in the textbooks illustrations and photos according to their sex. These are usually depicted in a stereotypical way, so that the sex of the person or character is not ambiguous. In addition, the contextual information available in the text was used as a basis for categorising the sex of the persons and fantasy characters. Characters and persons that we were not able to categorise as male or female are also included in the statistics and are referred to as 'other'. ${ }^{4}$ In addition to gender, attention is paid to the age of the persons, namely if they 
are described as adults or children (teenagers were categorised as 'children'). Second, gender bias in the vocabulary of the texts is explored by counting the number of the gendered references to male or female persons or fantasy characters. As the Finnish language has a genderless grammar (for example, no categorisation of third-person pronouns, cf. English she/he, or articles, cf. German der/dieldas; see Tainio 2006), only gender-specific words, that is, nouns that carry markings of gender in their semantics or in their form, are included. For example, first names (in Finnish these include denotations of sex) and such nouns as is ̈̈ 'father', täti 'aunt', prinssi 'prince' and virkamies ${ }^{5}$ 'civil servant' are included. Special attention is given to names referring to actual people as opposed to names referring to fictional persons and fantasy characters. Third, in reference to the results on gender-specific words, passages concerning equality or sexuality and gender division in culture and society are described.

\subsection{Visuals}

It is common for Finnish basic education textbooks to include many colourful illustrations (Tainio and Winkler 2014). A great majority of them feature people and fantasy characters. However, mathematics textbooks for the upper grades are an exception: most of the pictures are abstract. In terms of gender, the majority of the depicted persons and characters in the textbooks are male. The results of the quantitative analysis are shown in Table 8.1.

Table 8.1 shows that gender bias favouring pictures of males is most prominent in textbooks for mother tongue and literature (see also Tainio 2012). In our more detailed investigation (not shown here), we found that in textbooks on mother tongue, the preponderance of male characters is lowest in the third grade (males 58.5 per cent, females 24.8 per cent) and highest in the ninth (male 63.7 per cent, female 34.3 per cent). Most of the persons in the pictures were adults (4,204 combined), of whom 2,724 were

Table 8.1 Gender division in Finnish school textbook visuals

\begin{tabular}{lcccc}
\hline & Male & Female & Other & Combined \\
\hline Mother tongue & $5,313(61.3$ & $2,968(34.3$ & $384(4.4$ & $8,665(100$ \\
& per cent $)$ & per cent $)$ & per cent $)$ & per cent $)$ \\
Mathematics & $3,007(53.8$ & $1,762(31.6$ & $816(14.6$ & $5,585(100$ \\
& per cent $)$ & per cent $)$ & per cent $)$ & per cent $)$ \\
VocEdu & $244(52.8$ & $198(42.9$ & $20(4.3$ & $462(100$ \\
& per cent $)$ & per cent $)$ & per cent $)$ & per cent $)$ \\
Combined & $8,564(58.2$ & $4,928(33.5$ & $1,220(8.3$ & $14,712(100$ \\
& per cent $)$ & per cent $)$ & per cent $)$ & per cent $)$ \\
\hline
\end{tabular}




\section{Liisa Tainio and Ulla Karvonen}

men. There were 2,737 pictures of children, of which the majority were boys (1,503 boys, 1,234 girls).

The overrepresentation of males in the visuals is lowest in mathematics textbooks. Interestingly, in contrast to mother-tongue and literature textbooks, the overrepresentation of males was lowest in mathematics textbooks for the ninth grade; in these books most visuals featured males (53.6 per cent males, 43.1 per cent females). However, the ninth-grade textbooks contained fewer visuals of people than the other textbooks and had no visuals of fantasy characters. In the mathematics textbooks, there were fewer images of adults $(1,211)$ than of children $(2,223)$. The gender bias in these categories is interesting. While a large majority of images are of adult males (900 men to 291 women), among the images of children the bias is the opposite: only a small majority are of boys (1,021 girls, 1,080 boys). This might be a consequence of the fact that boys are more motivated to learn mathematics than girls, and thus girls have been encouraged by presenting them as actors in the field of mathematics almost as often as boys (Mattila 2005). However, the vast majority of images of male adults and fantasy characters create an impression of mathematics as a masculine sphere.

In the visuals of textbooks for vocational and educational guidance, the majority of images of are of children. The visuals focused on students' own perspectives on their present and future lives, which explains the preponderance of children (280 children, 153 adults). Most of the adults, were male (95 males, 63 females), and the majority of children were boys (149 boys, 131 girls). These textbooks contained only a few pictures of fantasy characters, of whom all (4) were females.

\subsection{Gender-specific Words and Gender Discussion}

Since the method used here to explore gender-specific words has been to count every occurrence of the type of word, the view of gender in texts is naturally limited. There could have been other ways to examine gender bias in these texts, but to gain an optimal overall picture of the texts this type of analysis was seen as most suitable, although it leaves a number of questions unanswered. However, such an analysis does reveal the frequency of the gendered references and shows the balance between females and males in the texts. Consequently, this approach is one way to explore the current manifestations of gender bias and to investigate whether it has become a naturalised phenomenon in Finnish school textbooks.

In all subjects and all textbooks, more words referred to males than to females (see also Tainio and Teräs 2010). The results of the analysis are shown in Table 8.2.

As Table 8.2 shows, in the textbooks for mother tongue and literature, gender-specific words referring to males appear much more frequently than words referring to females. Since mother-tongue and literature textbooks 
Table 8.2 Gender-specific words in Finnish school textbooks

\begin{tabular}{lccr}
\hline Reference to & Male & Female & Combined \\
\hline Mother tongue & $21,186(58.1$ & $15,253(41.9$ & $36,439(100$ \\
& per cent) & per cent $)$ & per cent \\
Mathematics & $4,089(54.9$ & $3,357(45.1$ & $7,446(100$ \\
& per cent) & per cent $)$ & per cent $)$ \\
VocEdu & $296(55.1$ & $241(44.9$ & $537(100$ \\
& per cent $)$ & per cent $)$ & per cent $)$ \\
Combined & $25,571(57.6$ & $18,851(42.4$ & $44,422(100$ \\
& per cent $)$ & per cent $)$ & per cent $)$ \\
\hline
\end{tabular}

contain many fictional and narrative texts, references in them to people are the most frequent. Again, the mother-tongue textbooks for ninth grade contain more references to males (60.8 per cent) than any other book; in one textbook as much as 65 per cent of gender-specific words referred to males. There are more references to actual (not fictional) men or boys (3,922 men and boys, 1,691 women and girls), but also references to fictional characters are overwhelmingly to males $(4,645$ males to 2,581 females).

The gender bias in the ninth-grade textbooks for mother tongue and literature is heavily affected by the curriculum. Books for ninth grade deal with the history of Finnish literature. In the tradition of Finnish literary history, male writers are presented as more significant than female writers (Schoolfield 1998). This is why we decided to count references to the writers who are most frequently referred to in the seven textbooks that are part of the data. The group of these writers consists of ten men and four women. In all but one textbook (Lentävä lause), the first and the second most frequently mentioned writers are men; in one of the textbooks there are no women among the five most frequently mentioned persons (Aktiivi), and in only one book there two women are among the five names (Aleksis).

From the point of view of quantitative analysis, the mother-tongue and literature textbooks seem to have the most noticeable gender bias, containing the vast majority of male visuals and references. However, on taking a closer look at the texts we found several sequences where students were informed of gender issues or were directed to analyse gender in different contexts, such as fiction or media representations, or where gender was focused on as in the orientations to the history of literature (see also Tainio and Teräs 2010:47-55). When learners were guided to study issues concerning the sociology of language or sociolinguistics, gender was identified as one feature influencing language use. However, in analyses of the structure of the Finnish language, the genderless character of the language typology 


\section{Liisa Tainio and Ulla Karvonen}

and the features of sexism in its use were not often mentioned-only in two of the seven ninth-grade textbooks, in fact.

In mathematics, a better balance of references to males and females is achieved, although a gender bias is still evident. In the textbooks for lower grades there are more gender-specific words referring to males, but in those for ninth-grade students the number of gender-specific words referring to males and females is almost equal (51.4 per cent references to males, 48.6 per cent to females). However, a gender bias is apparent in references to actual persons (245 references to men/boys, 57 to women/girls). In practice, almost all of the actual persons are adults, including scientists or mathematicians (such as Pythagoras or Leonhard Eules). This means that in the mathematics textbooks, adult men are more prominently represented than women and girls. All in all, the texts do exhibit a gender bias, but it is not significant.

In the mathematics textbooks, gender issues are never prominent. However, gender is embedded in the exercises in ways that encourage readers to dichotomise the two sexes and treat them as separate categories. There are exercises that instruct students to see, for instance, their own class as a group of people of male or female gender: they are asked, for example, to determine the percentage for both sexes. There are also exercises that involve comparing men's and women's results in sports. For example, students are asked to look at a table presenting javelin-throwing results from the past Olympic Games. Then they are asked to answer the following question: 'How much better was the men's result compared to the women's result in year a) 1964, b) 1988, c) 2004' (Laskutaito, Autumn Term, 16). In these kinds of comparisons men athletes are always 'better'. So, even if gender is not focused on in mathematics education, the ideology of gender is embedded in the textbooks through the visuals and the text.

The textbooks for vocational and educational guidance also contain more references to males than to females. In these books the majority of references to actual persons are more often to males. However, references to fictional female characters are more common (45 references to females, 35 to males). The textbooks for vocational and educational guidance explicitly mention gender, gender equality and gender segregation in education and the labour market. However, the influence of gender on people's individual abilities, opportunities and choices is seen from the point of view of personality and individual psychology. The textbooks include exercises such as: 'What are the benefits for a) a male if he is applying for a vacancy in a profession where most of the employees are women, b) a female if she is applying for a vacancy in a profession where most of the employees are men' or 'Explicate your answer! a) In which traditional women's professions is a man just as good as a woman?, b) In which traditional men's professions is a woman just as good as a man?' (Oma suunta, 89). In answering these kinds of questions, it is possible to take up the normative character of gender ideology as a specific topic of pedagogical discussion. However, it is 
up to the teacher whether this opportunity is used to support or question the prevailing gender stereotyping. Although the writers of textbooks seem to avoid supporting the prevalent gender segregation in the labour market, they nevertheless describe male and female students differently. Almost without exception, girls are seen as decent and hardworking, and boys are seen as wild or lazy and as having great difficulties with motivation.

\section{ANALYSING DISCUSSIONS BETWEEN THE TEACHERS}

Gender bias in the visuals and references became apparent only after a detailed investigation (Tainio 2012). To determine the kinds of observations teachers make when looking at textbooks, we organised two discussions between experienced teachers who did not know each other beforehand. The teachers were video-recorded when they sat at a table where there were mother-tongue and literature textbooks, and they were asked to 'think aloud' about which of the textbooks they would choose for their teaching (Sasaki 2008). They were then also asked to pay attention to the representation of gender and whether it promoted gender equality. In Discussion 1, the teachers, Mari and Sini, are subject teachers of mother tongue and literature. This means that their major subject at the university was either Finnish language (linguistics) or literature studies, and they have been trained to analyse different kinds of text. They are qualified to teach in the upper levels of comprehensive school (grades 7-9) and secondary schools. During the discussion, they examine textbooks for the ninth grade. In Discussion 2, the participants, Merja and Anne, are primary-level teachers. Their university major was education and pedagogy, and they are qualified to teach all subjects in the lower grades of comprehensive school (grades 1-6). These teachers are examining textbooks for the sixth grade. All four teachers are middle-aged women, teaching in the Helsinki metropolitan area.

The first impression concerning all of our data was that the teachers rarely talked about gender issues even if they were asked to pay attention to them. However, issues about multiculturalism and pupils who use and learn Finnish as their second language were discussed. This seems to be very common in discussions about equality and equity issues in the Finnish educational contexts of today. The conversation between the teachers in our main data reflected this tendency (see also example 3). For example, in Discussion 2, the teachers refer to multicultural issues even at the very beginning of their discussion. ${ }^{6}$

In this extract the teachers frame the discussion in terms of the problem of immigrant children. They take up the concept of families (line 6) as one of the key aspects when talking about the gender issues of pupils. They treat the problem of gender in terms of a minority culture (Somali girls, line 11) and thus indirectly as a problem in the moral order of a certain religion. In the Finnish context, Somali immigrants are almost without 


\section{Liisa Tainio and Ulla Karvonen}

Example 1 Discussion 2 (00.09-01.28)

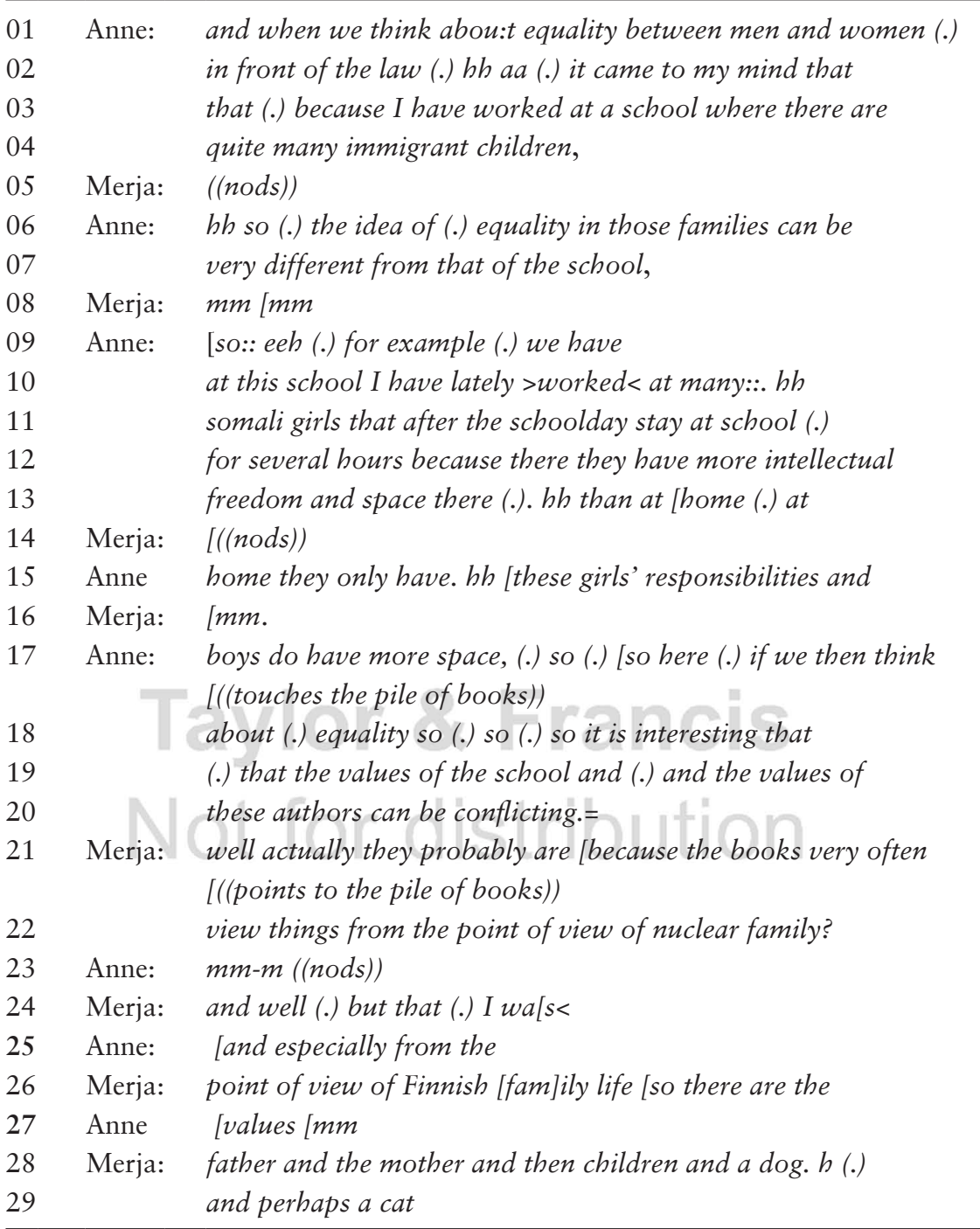

exception Muslim, while the vast majority, 78 per cent, of Finland's five and a half million inhabitants are members of the Lutheran church. ${ }^{7}$ When Anne takes up the problems of Somali girls, she refers to her own experiences and depicts Somali girls in an ideological framework that is common in current media discussions in Finland, seeing them more as victims of their culture than as individual actors (Dahlgren 2004; see also Roald 2001). In other words, gender equality is seen in connection with other aspects of 
Example 2 Discussion 2 (16.01-16.40)

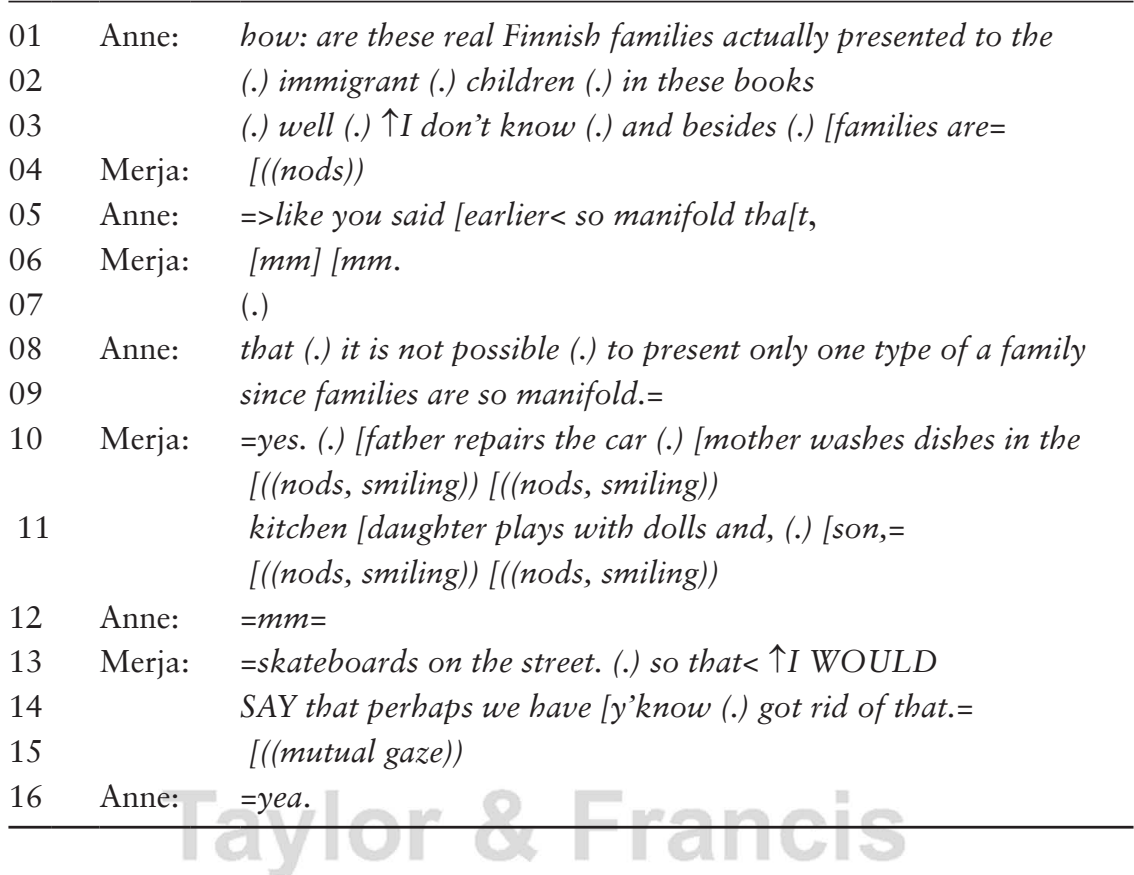

identity construction, such as ethnicity, cultural background and first language. However, this attitude locates the problems of gender equality as problems in minority cultures rather than more generally as a problem in Finnish society.

In their discussion, the teachers agree on the problem of school textbooks' grounding in Finnish values (lines 17-22). However, Merja specifies these values as referring to Finnish family values and depicts the Finnish family as consisting of a father, a mother, children, a dog and a cat (lines 28-29). In the following extract, later in the conversation the teachers return to the issue of immigrant pupils and the image of Finnish families:

In this extract, the teachers take up the issues of equity in terms of different kinds of families (lines 3-9). This is clearly connected to issues of gender ideologies, since the term 'manifold families' (lines 5 and 9), referring to the range of different kinds of families, includes families with, for example, only one parent or two mothers or two fathers. Raising the topic of the image of different kinds of families there, she also constructs a new image of gender that does not fit the stereotypical ones. Through describing how the traditional family looks, Merja depicts the consequences of Finnish family values, although in a humorous mode, smiling and accompanying the presentation with nonverbal emphases (lines 10-13). It is interesting that even if this description also applies to immigrant families, the 


\section{Liisa Tainio and Ulla Karvonen}

real Finnish family is understood as one whose members do not have an immigrant background. This becomes clear at the beginning of the extract, where Anne frames her opinion by contrasting a 'real' Finnish family and the families of immigrant children (lines 1-2). According to the teachers, the real Finnish family and its values consist of a heterosexual couple, with two children, a boy and a girl, living in a middle-class urban environment (having a car and a pet, boy skateboarding on a street). What is interesting is that this model of a stable nuclear family was well known in Western children's literature in the late nineteenth century and endured until the 1950s (Reynolds 2013:202). At the end of the extract, Merja says that this image is no longer offered to pupils in textbooks but denotes this only as a wish (e.g. with 'perhaps', see lines 13-14); she is not basing this observation in the data they have examined.

In addition to linking gender issues to problems with immigrant pupils, the teachers focus on three main aspects of gender. First they comment on the design of the book (visuals, layout), second on the orientations and contents of the literature offered and third on the image of the pupil/student reader and learner. The subject teachers in Discussion 1 comment particularly on the visuals, the representation of boys and girls and the number of images of female and male characters, an aspect that was clearly found to be biased in our analysis of the ninth-grade mother tongue and literature textbooks.

In Mari's first turn, the weak agreement between the teachers on the gender bias that does not favour women is taken up for further discussion. Even if Mari emphasises her observation about the vast majority of males in the visuals by using adverbs of certainty ('really'), she still adds a marker of uncertainty 'if I remember right' (line 4). Sini does not immediately agree with Mari's claim but receives it with an acknowledgement marker ahaa

Example 3 Discussion $1(54.00-54.25)$

\begin{tabular}{|c|c|c|}
\hline 01 & \multirow{3}{*}{ Mari: } & ((Mari leafs through a book, Sini looks $))$ \\
\hline 02 & & Wait a minute, if you think from the woman's (.)girl's (.) \\
\hline 03 & & point of view this illustration is if I remember \\
\hline 04 & & right (.) [really (.) [full $\uparrow$ of [boys hh.= \\
\hline & & {$[(($ nods $))[(($ nods $))[(($ nods $))$} \\
\hline 0 & Sini: & $=$ I see. \\
\hline 0 & & $(3.0)$ \\
\hline 07 & Sini: & Well $>$ there was a kind of skateboarding guy $<$ and, $=$ \\
\hline 08 & Mari: & $=M m$. \\
\hline 09 & Sini: & Yea. (.) So with that cartoon you try to get those boys or with \\
\hline 10 & & that kind of a character to get those boys somehow motivated. \\
\hline
\end{tabular}


Example 4 Discussion $2(20.23-21.02)$

\begin{tabular}{|c|c|c|}
\hline 01 & Anne: & if (.) we think about this colour palette it is quite gentle so= \\
\hline 02 & Merja: & $=m m-m ?=$ \\
\hline 03 & Anne: & $=$ so (.) so (.) have they thought more about girls (.) than boys \\
\hline 04 & & (.) I feel that< (.) okay this is perhaps again a kind of a \\
\hline 05 & & stereotype (.) but >somehow I feel that $<$ maybe boys are more \\
\hline 06 & & oriented to adventure, \\
\hline 07 & Merja: & $m[m$ \\
\hline 08 & Anne: & [so that they need (.) stronger experiences (.) and (.) \\
\hline 09 & & (.) and. hh stronger experiences appeal to boys so that \\
\hline 10 & & (.) so that the illustration should not be too \\
\hline 11 & & tame and Egir[lis]hE \\
\hline 12 & Merja: & {$[m m$,} \\
\hline
\end{tabular}

('I see') that denotes the claim as news (Hakulinen et al 2004:774). In this extract, Mari is the active initiator of new reference points for their observations. Nevertheless, after this sequence, the teachers both make comments on the images of males and females in the book that are more and more in line with each other's viewpoints. They critically comment on the tendency they seem to observe in the pictures of immigrants and Roma people, that is, of minorities, to emphasize pictures of women. They also comment on the few nonstereotypical images (a woman presented as a doctor; young men drinking coffee and not beer in a cafe). At the end of the sequence, where they talk about a noticeable male bias in the visuals, Sini concurs with Mari's attitude, saying, 'Surely these visuals quite overwhelmingly present men'.

The teachers in Discussion 2 pay particular attention to the layout of the books from a gender perspective. In the next extract they comment on the use of colour in the book design.

In this extract, Anne is commenting not only on the 'colour world' of the textbook (line 1) but also on her own image of gender. Although Merja's agreement is rather weak according to her minimal responses, the teachers nevertheless seem to agree on several aspects of gender ideology. First, they agree on the idea that boys and girls are different in that they are attracted to different things. Second, they agree on girls' and boys' basic characteristics: girls are tender, tame and 'girlish'; boys are adventurous and need strong experiences (lines 5-11). Third, in agreeing on these matters they also agree on the idea of girls and boys being different kinds of learners. Even if Anne labels her own description as gender stereotypical (line 4), they agree on these characteristics and connect them with a certain colour palette that is used in the textbook. They see this as problematic from the point of view of boys. 
Example 5 Discussion 1 (1.00.07-1.00.27)

\begin{tabular}{lll}
\hline 01 & Mari: & Just like those (.) the writers that are presented here, well it \\
02 & & is more or less this (.) Minna Canth that gets= \\
03 & Sini: & $=$ Yes. [She gets attention. \\
04 & Mari: & [among the women writers she (.) gets most (.) of the \\
05 & & $\begin{array}{l}\text { attention but otherwise there is more like (0.5) male } \\
06\end{array}$ \\
07 & Sini: & literalture here.
\end{tabular}

The second topic referring to gender bias, taken up in the discussions between the teachers, is orientations to literature as well as the content of fiction extracts presented in the textbooks. In particular, they comment on the protagonists' gender. In these discussions between the subject teachers, the orientation to female and male writers, for example, is a topic that surfaces several times. In the next extract, coming at the end of the discussion, the teachers summarise their observations on the frequency of female writers in the textbooks (see also Tainio 2012:220).

In the analysis of the textbooks we found out that Minna Canth, the writer about whom the teachers talk in this extract, is indeed presented as the most famous female writer in the history of Finnish literature, even if several male writers are seen as even more famous and important. Minna Canth is widely known as she fought for equal rights for women. This is why presenting Minna Canth in practice also means an opportunity to present information about the early feminist movements in Finnish society. All of the ninth-grade mother tongue and literature textbooks also used this opportunity to view the history of Finland from this angle. However, as a whole, the orientations to Finnish literature in the textbooks were gender biased, favouring male writers in Finnish cultural history. This bias was so evident that the teachers were easily able to see it.

Another topic addressed in the discussions on gender bias in literature education was the gender division of the protagonists in the fiction presented in textbooks. The sex and characteristics of the protagonists were seen as important, since the narration in children's literature is usually constructed in ways that invite the reader to identify with the main character and to share their emotions and views (Simons 2013). In the next extract the teachers seem to share this view and to see boys and girls as separate audiences with different expectations and needs in terms of identifying with protagonists, for example. The example begins with Anne's question, which reveals these presuppositions.

It is interesting that even if the discussion in the Finnish media has repeatedly echoed the opinion that Finnish school is designed more for girls than for boys (Jungar 2013), in this aspect of literacy education-the process 
Example 6 Discussion 2 (21.03-21.30)

\begin{tabular}{|c|c|c|}
\hline 01 & Anne: & $\begin{array}{l}\text { so (.) can we find (.) here like for example here } \\
\text { are the (.) }\end{array}$ \\
\hline 02 & & $\begin{array}{l}\text { extracts of fiction so (.) did you thi-> do you } \\
\quad \text { feel:: < tha:t (.) }\end{array}$ \\
\hline 03 & & $\begin{array}{l}\text { in the selection of these extracts they'd thought } \\
\text { about boys too, }\end{array}$ \\
\hline 04 & Merja: & $\begin{array}{l}\text { to my mind the selection of fiction is very much } \\
\text { carried out< }\end{array}$ \\
\hline 05 & & $\begin{array}{l}\text { like here the selections of books for [example } \\
\text { they }\end{array}$ \\
\hline 06 & Anne: & [yea \\
\hline 07 & Merja: & $\begin{array}{l}\text { actually are carried out pretty much on boys' } \\
\text { conditions, }\end{array}$ \\
\hline 08 & Anne: & $m m=$ \\
\hline 09 & Merja: & $\begin{array}{l}=\text { in the sense that those books are selected that } \\
\text { could appeal also to boys }\end{array}$ \\
\hline
\end{tabular}

of selecting fiction for pupils to read-Merja seems to treat this opinion critically. Anne's question (lines 2-3) contains the implication that boys and girls are different types of readers, but it also implies that fiction is mainly selected to meet the needs of girls. Merja refers to the textbooks they have on the table and concludes that the selections are made 'pretty much on boys' conditions' (line 5-7). At first, Anne appears not to fully agree with Merja's opinion (line 8), but when, in what follows after this extract, Merja confesses that she herself has chosen fiction for the class according to these conditions, Anne seems to begin to move towards full agreement. Furthermore, Merja gives examples of fiction featuring girls as protagonists that could appeal to boys also: there is Pippi Longstocking, Astrid Lindgren's joyful, physically strong and, in a way, anarchist girl character, and Matilda, Roald Dahl's character with special magical abilities. Merja also thinks that Lotta, another of Astrid Lindgren's characters, a small girl, is not a protagonist that boys would be interested in. In response to these examples, Anne again confirms her opinion of boys as readers who need strong experiences-and thus also strong characters and actors in narratives (see also example 4). The teachers seem to consider the process by which readers identify with the protagonists of narratives as quite straightforward, even if this identification in the reception of narratives is not particularly connected to the gender of the character (Simons 2013). However, if the variety of protagonists is heavily gender biased, this may after all help to promote equality and equity, even if the processes of identification are much more complicated than those assumed and presented in the discussions recorded in our data. 
Example 7 Discussion 2 (22.46-23.02)

\begin{tabular}{lll}
\hline 01 & Merja: & that somehow I just noticed hh that I read a lot about boys. \\
02 & Anne: & yea. \\
03 & & $()$. \\
04 & Merja: & Na:rnias well there are girl[s a]nd boys. \\
05 & Anne: & {$[y e a]$} \\
06 & Merja: & but then it changes then Prince Caspian becomes as a \\
07 & & protalgonist at a certain point and (.) so actually \\
08 & Anne: & {$[$ yea. } \\
09 & Merja: & one does not easily select a book where a girl is the protagonist.
\end{tabular}

As is also evident from the earlier examples, teachers reflect on their own thinking in response to the data. Their image of the pupils is one of the aspects of teacher thinking that influences the ways teachers interact with their students. These images are not stable but dynamic and develop throughout teachers' professional careers (Lavigne 2014). They are constructed in the context of the surrounding society and culture, certainly in interaction with other teachers, students and school staff but also in interaction with the cultural images offered, for example, by the media. Since the discussion around education in the Finnish context is loaded with gendered features, it is understandable that the teachers' reflections echo them. In the discussions in our data, it is common to view girls and boys as different kinds of students, with differing interests and motives, and boys as students with difficulties in going to school and learning and as not interested, for example, in mother tongue and literature.

In our detailed analysis of the textbook data, we did find a few androgynous characters in the visuals. The teachers also found traces of new kinds of gender ideology in the textbooks. In Discussion 2, the primary-level teachers reminisced about an earlier ABC book that was familiar to both of them: 'how they tried to turn upside down the stereotypes so that there was this girl a-bear who was the brave and curious and this boy who was timid and shy' (Anne, Discussion 2, 04.22). They also found traces of girls and boys being shown in a more androgynous manner in the visuals and texts: 'I don't know if that is a girl too-That looks like a modern girl-A tomboy anyway' (Sini and Mari, Discussion 1, 57.22). In addition, they found in children's literature certain nonstereotypical features describing the male protagonists' characteristics: 'these boys do have I won't say androgynous characteristics but anyway the kind of characteristics that they, as heroes, pay attention to other people too and have a certain gentleness and ability to take others into account' (Anne, Discussion 2, 23.15). 
All in all, the teachers in the two discussions reflected on their own teaching practices with regard to each other's descriptions and opinions and found grounds for self-criticism.

\section{CONCLUSION}

In this chapter, we have reported the results of an analysis of 59 textbooks used in Finnish basic education, written for mother tongue and literature, mathematics and vocational and educational guidance students. We also presented an analysis of discussions between teachers examining some of these textbooks.

The results of the analysis of the texts and visuals showed a gender bias even in the most recent body of Finnish school textbooks. The overriding feature was that in all textbooks and in all subjects the majority of pictures were of males and the majority of references were also to males. The textbooks contained passages about the meaning of gender in culture, language and society or about equality between genders. These were the most overt in textbooks for vocational and educational guidance but were also frequent in textbooks for mother tongue and literature. In mathematics textbooks, these issues were embedded in the instructions for exercises.

In the Finnish National Core Curriculum for Basic Education (2004:255), gender equality is mentioned as subject matter in the curriculum for vocational and educational guidance. As well, in teaching of mother tongue and literature this issue, along with the issue of gender organisation in culture and society, is often at the fore, although it is not mentioned in the curriculum of these subjects. In mathematics textbooks, gender distinctions sometimes appear in the exercises but are not as central as books used in teaching mother tongue and literature and vocational and educational guidance. All in all, gender matters are taken up in the textbooks, but quite rarely in view of the possibilities the subjects offer. Furthermore, the prevalent heteronormativity in Finnish culture and society was not mentioned in the textbooks. In the texts, heterosexuality was naturalised as the only and normal form of sexuality. However, in the visuals we found some characters depicted in ways that we could interpret as having been deliberately designed as androgynous.

The analysis of the conversations between the two pairs of teachers showed that when they observed textbooks in order to discuss their suitability for different learning purposes, such as learning about and discussing issues of gender organisation in culture and society, they were able to analyse the textbooks from certain perspectives. However, their observations focused only on the visuals and the overall content and orientations to literature presented in the textbooks. In another set of data, collected for other purposes, where teachers talked about learning materials and texts they use in their teaching, they did not pay attention to gender issues at all. 


\section{Liisa Tainio and Ulla Karvonen}

Even in the data we presented here, where the teachers were asked to pay attention to gender ideologies and equality issues, they nevertheless talked more about other textbook issues and ideologies. However, they seemed to at least notice the prevailing gender stereotyping. In addition, from time to time they also seemed to think along the lines of this stereotyping themselves, even if they appeared to be willing to adopt new ways of observing and thinking about gender. ${ }^{9}$ However, we found this method of having teachers talk to each other about textbooks a useful tool for reflecting on the ideas of gender or other attitudinal contents and for prompting teachers to reflect on their practices. Such a method could also be used in teacher education to provide future teachers with information and new ideas on gender equality, which they will be expected to promote in their work (Zittleman and Sadker 2002; Tainio 2012).

Gender bias in textbooks was addressed in Finnish media when the first report on the issue by Tainio and Teräs (2010) was launched. The discussion was lively but short. The news sources viewed gender bias in textbooks as problematic. The ensuing comments on the newspapers' webpages were quite emotional and consisted mainly of opinions that the topic was unimportant and even ridiculous. However, the fact that there were so many comments revealed that this issue was not seen as trivial. After launching the report, its publisher, the Finnish National Board of Education, also provided a detailed recommendation to Finnish textbook publishers to pay more attention to gender ideology and gender bias in their textbooks. ${ }^{10}$ The recommendations have, unfortunately, not yet had a noticeable effect on the content of recent textbooks. However, at the official level some effort has been made to tackle the prevailing gender bias in Finnish textbooks. Much still remains to be done. Our analysis of gender bias in these textbooks shows that although more progress can still be made, there are even now signs of change. For example, some of the newest textbooks feature pictures of people intentionally depicted as androgynous. There are also characters not described in the texts or visuals as presenting the traditional gender roles. We also found rare cases in textbooks in which we could discern the intention to present nonheterosexual relations between two persons. So, even if the recommendations to publishers are not yet manifested in the quantitative analysis of the textbooks, we feel optimistic about change, even though it is very slow (Zittleman and Sadker 2002). Since there are new trends concerning, for example, the image of the families, both Finnish and international children's literature is more often depicting families with members in different kinds of relations and having different sexual identities (Reynolds 2013. Thus, it can be expected that with respect to school textbooks change is also possible. Even if school textbooks are usually designed to be as neutral as possible to best suit everyone both at school and at homes, conceptions of genders and sexualities, as well as ideologies concerning gender and sexuality, will, we hope, be more open in the future. 


\section{Appendix 1}

Example 1 Discussion $2(00.09-01.28)$

01 Anne: että siinähän jos me aatellaan niin: miehen ja naisen tasa-arvoo (.)

05 Merja:

06 Anne:

07

08 Merja:

09 Anne:

14 Merja:

15 Anne

16 Merja:

$[($ touches

the pile of books))

21 Merja:

23 Anne:

24 Merja:

25 Anne:

26 Merja:

27 Anne:

28 Merja:

29 arvoo (.) lain edessä (.). hh öö mutta (.) tuli mieleen tämmönenki näkökulma että (.) ku mä oon sellasessa koulussa missä on huomattavan paljon maahanmuuttajalapsia, ((nods)) .hh niin (.) näiden perheiden käsitys (.) tasa-arvosta voi olla erilainen ku mikä on koulun käsitys, $\mathrm{mm}[\mathrm{mm}$

[että: eeh (.) esimerkkinä tämmönen että (.) että kun (.) meillä on koulussa paljon:: täs koulussa missä viimeks >oon ollu ni<. hh näit somalityttöjä jotka jäi koululle (.) koulupäivän jälkeen useammaks tunniks sen takia että heil oli siellä sitä henkistä vapautta ja liikkumatilaa (.). hh enemmän ku [kotona (.) koska $[(($ nods $))$

heillä oli sit vaan nää. hh [tai nää tytön velvollisuudet et pojal on $[\mathrm{mm}$.

enemmän tilaa, (.) et (.) että [tässä (.) et jos nyt tarkastellaan

$$
\text { myös }
$$

)

niinku (.) tasa-arvoo niin (.) niin (.) ni on mielenkiintosta ajatella sitä että (.) että koulun arvot ja (.) ja näiden kirjantekijöiden: arvot voi olla ristiriidassa joidenki kotien arvojen kanssa.= =kyllä varmaan on:ki koska [kirjathan hirveen usein lähtee [((points to the pile of books $))$ semmosesta ydinperheestä?

mm-m ((nods)) ja tota: (.) mut sitä (.) mä oli[n< [ja suomalaisesta nimenomaan [suomalaisesta per]hemaai[lmasta että [arvomaailmasta] [mm on isä ja äiti ja siinä on sitte lapset mukana ja koira. h (.) ja ehkä kissa. 
Example 2 Discussion $2(16.01-16.40)$

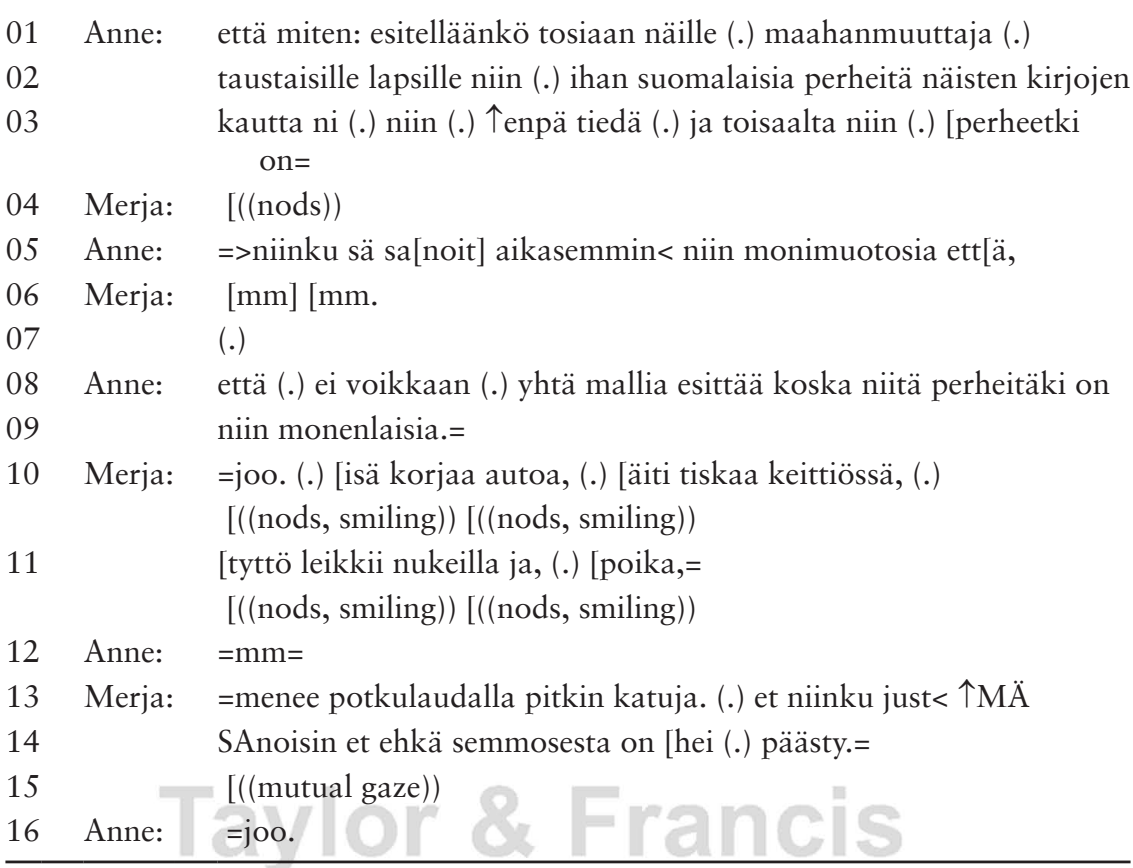

Example 3. Discussion 1 (54.00-54.25)

$01 \quad$ ((Mari leafs through a book, Sini looks))

02 Mari: Hetkinen, jos tätä tästä n- nai- nainen, (.) tyt- tyttö poika (.)

03 näkökulmasta niinku aattelee, ni siinähän suhteessa tää piirroskuvitus on 04 muistaakseni (.) [todella (.) [täyn $\uparrow$ nä [poikia hh.= kyl (.) $[(($ nods $))[(($ nods $))[(($ nods $))$

05 Sini: =Ahaa.

$06 \quad$ (3.0)

07 Sini: No $>$ siin oli ainaki tällanen skeittityyppi< ja,=

08 Mari: $=$ Mm.

(.)

09 Sini: Yea. (.) So with that cartoon you try to get those boys or with 10 that kind of a character to get those boys somehow motivated. 
Example 4 Discussion 2 (20.23-21.02)

01 Anne: mitenkä (.) jos aatellaan tätä värimaailmaa se on aika hempeä että=

02 Merja: = mm-m?=

03 Anne: =että (.) että (.) onko näis ajateltu enemmän tyttöjä (.) kuin poikia että

04 onko (.) tuntuu että< (.) no joo tää on ehkä taas tämmönen

05 stereotypia (.) mutta >jotenki tuntus että< enemmän ehkä pojissa on

06 tiettyä seikkailuorientoitunutta,

07 Merja: $\mathrm{m}[\mathrm{m}$,

08 Anne: [piirrettä et pitäs olla jotaki (.) vahvempia elämyksiä ja (.) ja (.) ja

09 jotaki sellasta (.). hh voimakkaampaa mikä: vetoais myös poikiin että

10 et (.) joka on: (.) ettei oo liian tämmöst kesyä ja

$11 \quad £$ tyt [tö]mäistä $£=[$

12 Merja: [mm,] [mm:

Example 5 Discussion 1 (1.00.07-1.00.27)

\begin{tabular}{|c|c|}
\hline 01 & Mari: Ihan niinku tavallaan ne (.) kirjailijat joita tääl nostetaan nin, (.) niin \\
\hline 02 & se on lähinnä toi (.) Minna Canth joka= \\
\hline 03 & $=$ Niin. $[$ Se nousee sieltä. \\
\hline 04 & Mari: [naiskirjailijoista niinku (.) parhaiten, (.) on esillä mutta (.) \\
\hline 05 & muuten se on aika $(0.5)$ äijäin \\
\hline 06 & kirjallisuut[ta tää. \\
\hline 07 & Sini: [Niin. \\
\hline
\end{tabular}

Example 6 Discussion 2 (21.03-21.30)

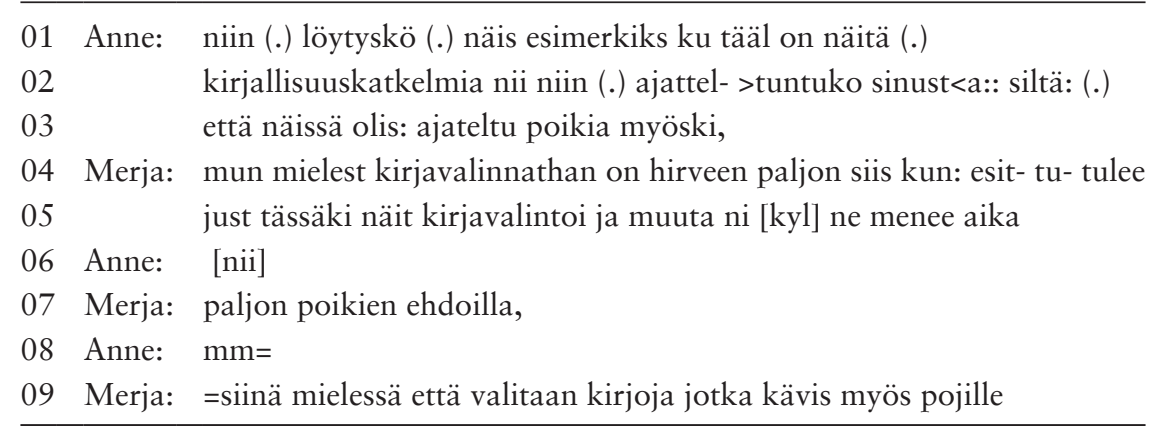


Example 7 Discussion 2 (22.46-23.02)

\begin{tabular}{lll}
\hline 01 & Merja: & et jotenki mä huomasin vaan itse hh lukevani paljon pojista. \\
02 & Anne: & joo. \\
03 & & $()$. \\
04 & Merja: & Na:rnia no siin on tyttöjä [ja] poikia. \\
05 & & Anne: [nii] \\
06 & Merja: & mut sit se muuttuu prinssi Kaspian muuttuu päähenkilöks [siin] \\
07 & Anne: & [nii] \\
08 & Merja: & $\begin{array}{l}\text { yhessä vaiheessa ja (.) et hyvin paljon että ei helposti valitse kirjaa } \\
\text { missä on tosiaan tyttöpäähenkilö. }\end{array}$ \\
& &
\end{tabular}

\section{Appendix 2}

Transcription conventions follow the tradition of conversation analysis (see e.g. Sidnell and Stivers 2013).

The used transcription conventions are the following:

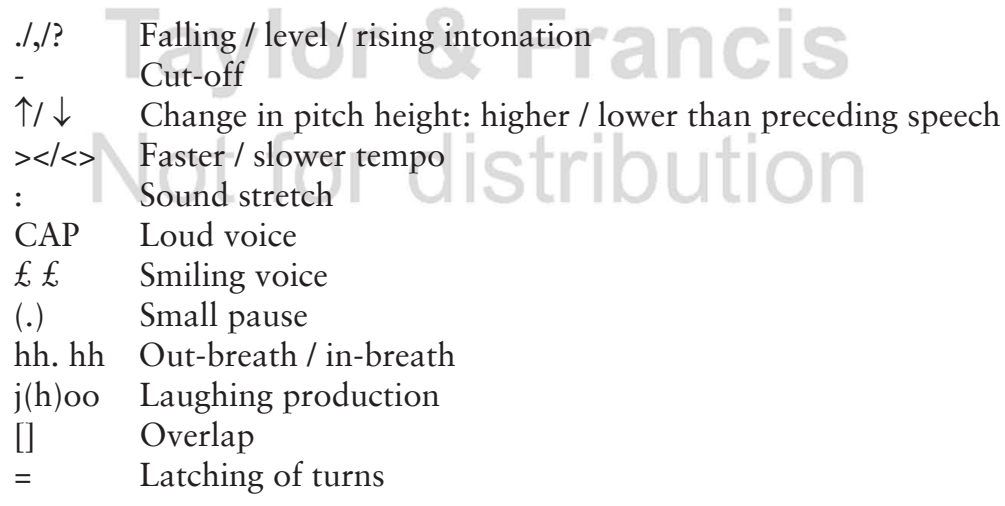

\section{NOTES}

1. This subject is called 'mother tongue and literature' in the Finnish national curriculum; we will use this name further on in this chapter.

2. These publishers are Edita, Otava and SanomaPro (which includes the publishers of learning material previously known as Tammi and WSOY). The data have been selected from the publishers' websites, and all books are included, as there is only sporadic information on which textbooks are actually used in schools (e.g. Luukka et al 2008:91; Tainio and Winkler forthcoming).

3. The gendered image of these subjects also appears in the gender division of the textbook writers. Even if the preponderance examined here favoured women (155 women, 73 men), there was an exception: for ninth-grade mathematics textbooks, male authors form a majority (16 men, 8 women). 
4. These 'others' might have been depicted from a distance, which often makes the categorisation impossible, and sometimes the persons were depicted as androgynous.

5. The word virkamies includes the ending '-mies', which means 'man'; this word is seen as a generic masculine form since it is also used for civil servants who are women (Engelberg 1993).

6. The examples are presented in the original Finnish in Appendix 1 in the end of this chapter. The transcription conventions are available in Appendix 2.

7. There are altogether between 50,000 and 60,000 Muslims in Finland (Martikainen 2011).

8. The Chronicles of Narnia by C. S. Lewis.

9. Of course, the fact that they were conversing in an organised situation and in front of a camera might have had some influence on the topics and stances they were taking

10. These activities were also encouraged by the project 'Gender awareness in teacher education' (2008-2011), conducted at Finnish universities, with funding from the Ministry of Education, and directed by Professor Elina Lahelma (see TASUKO website, http://wiki.helsinki.fi/display/TASUKO/ [accessed February2, 2014]).

\section{Taylor \& Francis Not for distribution}

